\title{
Finding During Childbirth Labor
}

National Cancer Institute

\section{Source}

National Cancer Institute. Finding During Childbirth Labor. NCI Thesaurus. Code C92718.

Symptom, signs, test results in a pregnant mother childbirth. 